\title{
INVESTIGATING COMPLIMENT RESPONSE STRATEGIES IN AMERICAN ENGLISH AND VIETNAMESE UNDER THE EFFECT OF SOCIAL STATUS
}

\author{
Nguyen Thi Thuy Linh* \\ VNU University of Languages and International Studies, \\ Pham Van Dong, Cau Giay, Hanoi, Vietnam
}

Received 10 March 2020

Revised 8 June 2020; Accepted 25 July 2020

\begin{abstract}
The present study seeks to investigate the effect of the social status on the use of compliment response (CR) strategies in American English and Vietnamese. To this end, two sets of data were collected with the help of a discourse completion task (DCT) illustrating twelve situational settings in which compliments were produced by ones of higher, equal, and lower status with the informants. Statistical analysis provides descriptive statistics results in terms of $\mathrm{CR}$ strategies on macro- and micro-level, i.e. these findings demonstrate the CR strategies of acceptance, amendment, non-acceptance, combination, and opting out. Furthermore, inferential statistics have revealed if there is a global standard in the use of CRs between American and Vietnamese native speakers. Finally, the results suggested a significant effect for the treated intervening social variable of status in determining the type of CRs.
\end{abstract}

Keywords: compliment, compliment response, social status

\section{Introduction}

Complementing behavior is a universal linguistic phenomenon. As a speech act which happens with a high frequency in our daily life, it plays a significant communicative function and serves to establish, consolidate, and promote interpersonal relationships (Holmes, 1988). A proper complementing behavior can make people closer and more harmonious. Being an adjacency pair, a compliment and a compliment response (CR) coexist. The responses to the compliment vary due to the social and individual elements. Different cultural customs, communicative

* Tel: 84-362328288

Email: nthithuylinh88@gmail.com topics, social power, gender, and educational background, etc. will affect compliment responses.

To explore compliment responses used by American and Vietnamese native speakers under the influence of social status factor, the study intends to answer the following question: How does status affect the choices of compliment response strategies in both American and Vietnamese groups of native informants?

\section{Literature review}

Compliment responding is considered the speech act that has attracted the most abundant studies in the field of pragmatics. Early work on $\mathrm{CR}$ research concentrated on different 
varieties of English: American English by Herbert (1986, 1990), Manes (1983), Pomerantz (1978, 1984) and Wolfson (1983); South African English by Herbert (1989), and New Zealand English by Holmes (1988). These pioneering studies have revealed much about the various facets of both compliments and CRs: the things that are most likely to be complimented on, the kinds of interlocutors that one is likely to make compliments to, and the syntactic structures that are most often used in English for compliments and CRs, and the pragmatics of $\mathrm{CR}$ strategies adopted in each of these English-speaking communities.

Serious attention began to be given to CRs in other languages and cultures beginning from the 1990s. While a comprehensive review of research on compliments and CRs is seen in Chen (2010), the following sampler provides a glimpse of this vast amount of literature: Nigerian English by Mustapha (2004); Polish by Herbert (1991) and Jaworski (1995); German by Golato (2002); Spanish by Lorenzo-Dus (2001); Turkish by Ruhi (2006); Persian by Sharifian (2005); Jordanian Arabic by Farghal and Al-Khatib (2001) and Migdadi (2003); Kuwaiti Arabic by Farghal and Haggan (2006); Syrian Arabic by Nelson et al. (1996); Japanese by Daikuhara (1986), Baba (1999), Fukushima (1990), and Saito and Beecken (1997); Korean by Han (1992); Thai by Gajaseni (1995); and Chinese by Chen (1993), Yu (2004), Spencer-Oatey and $\mathrm{Ng}$ (2001), Yuan (2002), and Tang and Zhang (2009), among others.

These studies have discovered many subtleties and nuances about the similarities and differences among this rich diversity of languages. Speakers of German, for instance, are not found to use appreciation tokens (e.g., "Thank you") in CRs, although they accept compliments as much as do Americans
(Golato, 2002). In Thai, social status is found to be a factor influencing speakers' CR behavior: a compliment that flows from someone in higher social status to someone in lower social status is more likely to be accepted than one that flows in the opposite direction (Gajaseni, 1995). Instances of "impoliteness" are found in the Turkish data, whereby the complimenter explicitly challenges the assumption of the compliment (Ruhi, 2006, p. 70). Arabic speakers, on the other hand, are found to routinely "pay lip-service" (Farghal and Haggan, 2006, p. 102) to the complimenter, using a set of formulaic utterances to offer the object of the compliment to the complimenter without meaning it. In addition, gender-based differences in CRs have been attested in a number of languages. Herbert (1990), for example, finds that compliments delivered by American males are twice likely to be accepted than those delivered by females and females are twice likely to accept compliments than are males.

The diversity of findings in the literature on CRs is mirrored by the diversity of theoretical orientations these researchers adopt. Early work on CRs was informed by ethnography, sociolinguistics, sociology, and conversation analysis. Beginning from Holmes (1988), theories of politeness began to be used by researchers to account for their findings. These politeness theories, particularly Brown and Levinson's theory, have been the dominating theoretical framework for CR researchers, although not all of them have been found adequate (e.g., Chen, 1993; Ruhi, 2006).

Recent years have seen proposals of new theoretical constructs in CR research. Sharifian (2005) explains Persian CRs in terms of cultural schemas, arguing that Persian CRs are motivated by the schema of shekastehnafsi "broken self," glossed as "modesty" 
or "humility." Finding classical theories wanting in their explanatory adequacy to inform CR's in Turkish, Ruhi (2006) proposes the notion of self-politeness-based on but different from Chen's (2001) model of selfpoliteness-which includes three aspects: display confidence, display individuality, and display impoliteness. Ruhi and Doğan (2001), on the other hand, posit that Sperber and Wilson (1993) theory of relevance is a viable alternative to account for the cognitive processing of compliments and CRs in Turkish.

Researchers in $\mathrm{CR}$ research have also adopted a range of taxonomies for categorizing CR utterances. Pomerantz's (1978, p. 81-82) seminal work on CR identifies two conflicting constraints facing a compliment responder:

\section{A. Agree with the complimenter}

\section{B. Avoid self-praise}

Constraint A explains acceptance of compliments, often expressed by appreciation tokens (e.g., "Thank you"). Constraint B motivates those strategies that downgrade the value of the objects of compliments (e.g., "That's a beautiful sweater!" "It keeps out the cold") or to shift the credit away from the responder herself (e.g., "That's a beautiful sweater!" "My best friend gave it to me on my birthday"). These two general principles are refined into three categories in Herbert (1986): Agreement, Non-Agreement, and Other Interpretations. Under each of these three categories are several subtypes of responses. While this taxonomy has been popular, it has not been the only one. Holmes' (1988) system of classification, for example, is clearly different, whereby she classifies 12 types of CRs - labeled differently from Herbert's-into three broad categories: Acceptance, Deflection/Evasion, and Rejection. Yu (2004) groups her Taiwanese CRs into six types. Yuan (2002) uses yet another system of labels for the 12 semantic formulas she has identified from her Kunming Chinese data, including two that have not been identified in previous studies: invitation and suggestion.

In spite of this wide variety of taxonomies, however, one can discern a convergence in the way CRs are categorized, that the tripartite system - Acceptance, Deflection/ Evasion, and Rejection - originally proposed by Holmes (1988) and supported by Han (1992) and Chen (1993) - has been gaining currency (Ruhi, 2006; Tang and Zhang, 2009; among others). This taxonomy, first, reflects the insights of Pomerantz's (1978) constraints as seen above. The need to agree with the complimenter motivates the acceptance of a compliment; the need to avoid self-praise motivates the rejection of a compliment, while the need to strike a balance between the two constraints leads to utterances that mitigate-either deflect or evade the compliment.

To reflect the nature of the data collected, both regarding the American and Vietnamese data sets, I decided to embed some of the compliment response strategies nominated by $\mathrm{Yu}$ (2003). The annexation of Ruhi's taxonomy (2006) is reflected through the inclusion of the sub-category of Appreciation (token + comment,) as an acceptance strategy and addition of three combination strategies on macro-level. This macro-level strategy - Combination - accounts for the responses manifesting two sub-categories of the macrolevel strategies of Acceptance, Deflection/ Evasion or Rejection. The following table depicts the chosen taxonomy of compliment responses that I have adapted and employed for the analysis. 
Table 1: Adapted taxonomy of Compliment responses

\begin{tabular}{|c|c|c|}
\hline $\begin{array}{l}\text { Macro-level } \\
\text { strategies }\end{array}$ & Micro-level strategies & Example \\
\hline \multirow[t]{7}{*}{ I. Acceptance } & Appreciation token & $\begin{array}{l}\text { - Thank you! } \\
\text { (Cám ơn!) }\end{array}$ \\
\hline & Agreement & $\begin{array}{l}\text { - Yeah, it is. } \\
\text { (Đúng vậy!) }\end{array}$ \\
\hline & Expressing gladness & $\begin{array}{l}\text { - I am so glad that I can help! } \\
\text { (Mình rất vui vì có thể giúp được cậu!) }\end{array}$ \\
\hline & Upgrade & $\begin{array}{l}\text { - Maybe it's because I'm very active. } \\
\text { - Damn it, I'm perfect. } \\
\text { (Chuyện! Tao chỉ có là hoàn hảo!) }\end{array}$ \\
\hline & Joke & $\begin{array}{l}\text { - What a cute chubby little boy! } \\
\text { - Cute as his mom and chubby as his dad! } \\
\text { (- Ôi em bé dễ thuoong mũm mĩm yêu quá! } \\
\text { - Uh, dễ thuoong giống mẹ còn mũm mĩm giống bố!) }\end{array}$ \\
\hline & Laughter & $\begin{array}{c}\text { You look smarter with this new laptop! - [Loud } \\
\text { laughter] } \\
\text { (- Có con máy mói nhìn ngon hẳn! } \\
\text { - Haha) }\end{array}$ \\
\hline & Acceptance association & $\begin{array}{l}\text { - Thank you! I am so glad you like it! } \\
\text { (Cám on! Mình rất vui vì bạn thích!) }\end{array}$ \\
\hline \multirow[t]{6}{*}{ II. Amendment } & Return & $\begin{array}{l}\text { - Your mother used to cook very well, too. } \\
\text { (Mẹ bạn nấu ăn cũng rất ngon đấy!) }\end{array}$ \\
\hline & Downgrade & $\begin{array}{l}\text { - It's my duty, I do it with pleasure. } \\
\text { (Đây là trách nhiệm của mình mà!) }\end{array}$ \\
\hline & Question & $\begin{array}{l}\text { - You look smart with the new laptop! - What do } \\
\text { you mean to "look smart”? } \\
\text { (Bạn trông thật bảnh với chiếc máy tính móii! - Ý } \\
\text { bạn "bảnh" là thế nào?) }\end{array}$ \\
\hline & Comment & $\begin{array}{c}\text { - Your dress looks nice. } \\
\text { - I bought it yesterday. } \\
\text { (Váy đẹp nhi!- Mình mói mua hôm qua!) }\end{array}$ \\
\hline & Transfer & $\begin{array}{c}\text { - I couldn't have done it without you. } \\
\text { (Nếu nhu không có cô, em không thể có được ngày } \\
\text { hôm nay!) }\end{array}$ \\
\hline & Amendment association & $\begin{array}{l}\text { - Really? You think so? Honestly I just thought I } \\
\text { was lucky. } \\
\text { (Thật sao? Bạn nghĩ vậy u? Thực tình mà nói mình } \\
\text { chỉ ăn may thôi!) }\end{array}$ \\
\hline
\end{tabular}




\begin{tabular}{|c|c|c|}
\hline \multirow[t]{4}{*}{ Non-acceptance } & Disagreement & $\begin{array}{l}\text { - I don't think so. } \\
\text { (Minh không nghĩ vậy!) }\end{array}$ \\
\hline & Qualification & $\begin{array}{c}\text {-You must be very smart. You did well on the } \\
\text { previous exam. } \\
\text { - Not really, you did better. } \\
\text { (Cậu giỏi thật đấy! Bài kiểm tra hôm nọ làm siêu } \\
\text { thật!- Không hằn, cậu làm tốt hơn.) }\end{array}$ \\
\hline & Diverge & $\begin{array}{l}\text { - You did well on the previous exam! } \\
\text { - Let's try to study harder and get the scholarship! } \\
\text { (Bài kiểm tra hôm no cậu làm giỏi thật!- Chúng } \\
\text { mình cùng cố gắng học hành chăm chỉ hơn để lấy } \\
\text { họ bổng nhé!) }\end{array}$ \\
\hline & $\begin{array}{l}\text { Non-acceptance } \\
\text { association }\end{array}$ & $\begin{array}{l}\text { - No, you did a better job. Why don't we get a } \\
\text { drink after school? } \\
\text { (Không, cậu làm tốt hơn. Chúng mình sau giờ học } \\
\text { đi uống nước đi!) }\end{array}$ \\
\hline \multirow[t]{3}{*}{ IV. Combination } & $\begin{array}{l}\text { Combination } 1 \\
\text { (accept+amend) }\end{array}$ & $\begin{array}{l}\text { - Thank you. I couldn't have done it without you. } \\
\text { (Cám ơn thầy. Em không thể được như vậy nếu } \\
\text { không có thầy chỉ bảo.) }\end{array}$ \\
\hline & $\begin{array}{l}\text { Combination } 2 \text { (accept } \\
\text { and non-accept) }\end{array}$ & $\begin{array}{l}\text { - Pleasure was all mine. Let's study harder next } \\
\text { term. } \\
\text { (Đây là niềm vinh hạnh của tớ. Kì tới học hành } \\
\text { chăm chì hơn nhé!) }\end{array}$ \\
\hline & $\begin{array}{l}\text { Combination } 3 \text { (amend } \\
\text { and non-accept) }\end{array}$ & $\begin{array}{l}\text { - I tried really hard to get the scholarship but } \\
\text { honestly you deserved it more than me. } \\
\text { (Tớ đã cố gắng rất vất vả để giành học bổng đấy } \\
\text { nhung kì thucc, tớ thấy cậu xúng đán hơn tớ:) }\end{array}$ \\
\hline \multirow[t]{4}{*}{ V. Opting out } & Opting out with fillers & $\begin{array}{l}\text { - You look great!- Awwwww } \\
\text { (Uầy! Trông ngon đấy!) }\end{array}$ \\
\hline & $\begin{array}{l}\text { Opting out without } \\
\text { anything/ no } \\
\text { acknowledgement } \\
\text { (silence) }\end{array}$ & $\begin{array}{l}\text { - You look smart with the new laptop! - [Silence] } \\
\text { (Có máy tính móti nhìn sáng sủa hắn!- [Im lặng]) }\end{array}$ \\
\hline & $\begin{array}{l}\text { Opting out with topic } \\
\text { change }\end{array}$ & $\begin{array}{l}\text { - What a nice car! - What do you think of the } \\
\text { color? } \\
\text { (Xe mói đẹp nhì- Cậu nghĩ sao về màu son xe?) }\end{array}$ \\
\hline & $\begin{array}{c}\text { Expressing } \\
\text { embarrassment }\end{array}$ & $\begin{array}{l}\text { - You are so good at it! - Oops, I am embarrassed. } \\
\text { (Giỏi quá co!! - Ôi, ngại quá!) }\end{array}$ \\
\hline
\end{tabular}

\section{Methodology}

\subsection{Participants}

The overall population of participants in this study was 237 , which was divided quite evenly into two big groups- American natives and Vietnamese natives. In the American group, the number of female respondents was 61 while 56 of them were male. The Vietnamese group also had a tendency that 
more female informants took part in the study than male ones. Out of 120 Vietnamese participants, 68 ones were female while the number of male ones was 52 .

Recruiting informants was based on two criteria that decided upon whether an informant was eligible for the research or not. Each informant was asked two questions and a positive answer to both of them qualified them as potential participants. The two criteria are those related to the country of birth and their mother tongue.

Criteria questions for recruiting informants for the study:

- Are you native speaker of American/ Vietnamese?

- Were you born in the U.S/Vietnam?

Some tendencies of how American and Vietnamese informants have been found are discovered and my considerations on this very process might be of some help to future researchers with similar research methodology criteria who will embark on the quest for study participants.

Table 2: Participants' characteristics

\begin{tabular}{ccc}
\hline Speaker group & American & Vietnamese \\
\hline Number offemales & 61 & 68 \\
\hline Number of males & 56 & 52 \\
\hline
\end{tabular}

\subsection{Research instruments}

A pilot DCT was designed and tested. The purpose of this trial run was to identify the existing flaws in the wordings and order of the questions as well as potential practical problems in following the research procedure. In particular, it tested the social variables set out in the research questions (gender social status and topics of compliments). The initial version of the DCT was distributed to a female Vietnamese $\mathrm{PhD}$ candidate who is an experienced TESOL practitioner as well as an English-Vietnamese proficient translator and a male American researcher in COE College who is living in Iowa. They were asked to comment on the appropriateness of the content and wording after they had finished filling it in. A Vietnamese version of this DCT was also sent to 23 second-year students of International Standard Program in Faculty of English, the University of Languages and International Studies, Vietnam National University. The responses gathered from the pilot test were used as reference for improving the final version of the DCT.

Because the DCT was first constructed in English and was later translated into Vietnamese, cultural transposition had to be considered (Blum-Kulka, House \& Kasper, 1989, p. 274). Accordingly, the Vietnamese social context had to be taken into account in the process of translation. Several factors may affect the quality of the translation: the translator's linguistic competence, her knowledge of the culture and the people under study, the autobiography of those involved in the translation, and the circumstances in which the translation takes place (Temple, 1997, p. 610). The DCT, first constructed in English, was therefore translated into Vietnamese by the researcher, then a proficient bilingual translated the Vietnamese back into English for comparison with the original English version for mismatches and any changes needed to ensure conceptual equivalence.

The DCT used in this research consisted of two parts, the first one is the introduction to the survey and the second section contains 12 situations which were discreetly constructed to investigate the gender, social status and complimenting topic variables. Full versions in both languages of the DCT can be found in the Appendix.12 situations are named as in the following table: 
Table 3: List of situations in the DCT Questionnaire

\begin{tabular}{cccc}
\hline Situation 1: & Thesis defense & Situation 7: & Weight loss \\
\hline Situation 2: & Help at meal & Situation 8: & New car \\
\hline Situation 3: & Nice outfit & Situation 9: & Scholarship \\
\hline Situation 4: & First baby & Situation 10: & Helping friend \\
\hline Situation 5: & Inspiring lesson & Situation 11: & New haircut \\
\hline Situation 6: & Humorous boss & Situation 12: & New MacBook \\
\hline
\end{tabular}

With an aim to investigate the social status variable, compliments in situations 1-4 are issued by complimenters of high social status to recipients of low social status. Thus, the compliment response will flow from Low (L) status to High $(\mathrm{H})$ status. Compliments in situations 5-8 are issued by complimenters of low social status to recipients of high social status. That is, the compliment response will flow from High $(\mathrm{H})$ status to Low (L) status. The characters chosen to represent a person of high social status included a boss at work, a supervisor, and mother-in-law. Low status characters were represented by a university student, a subordinate, a daughter/son-inlaw and a nephew/niece. Compliments and compliments responses in situations 9-12 are interchanged between friends. Thus, the compliment response flows horizontally between colleagues and peers, that is, between two persons of equal social status.

Table 4: Social status distribution in the DCT questionnaire

\begin{tabular}{ccc}
\hline High to low & Low to high & Equal \\
Situation 1 & Situation 5 & Situation 9 \\
Situation 2 & Situation 6 & Situation 10 \\
Situation 3 & Situation 7 & Situation 11 \\
Situation 4 & Situation 8 & Situation 12 \\
\hline
\end{tabular}

\subsection{Data collection procedure}

The DCT questionnaire was administered in person to both groups of respondents who were given adequate time to complete the surveys at their own pace. The reason behind was the fact that due to the relatively high number of openended questions (12 items) seeking spontaneity in providing responses would possibly touch the borders of affective factors such as stress leading to unreliable records.

Importantly, during the coding of the compliment responses, a sample of each corpus was examined by two other raters (one male and one female) to achieve inter-rater reliability. For each part, $20 \%$ of the data were randomly exposed to recoding by a second and third rater as suggested by Cohen (1960, as cited in Yu, 2005, p. 98). In this way, another sex-based confound would be remedied for through coming up with an average reliability rate of these two opposite sex-coders.

\subsection{Data analysis}

The DCT data will be statistically analyzed using IBM statistical software package SPSS. Data were coded for social status (higher, lower, and equal status). Social status was defined as institutionalized role (teacher, student), family role (mother, daughter-in-law, etc.), or age (senior, junior colleague. Using these distinctions as a base, I coded status as a binary-value, that is, either 
the addressee was higher status (+ status) or low status (- status) (cf. Yu, 2004). The coded data of the DCTs were analyzed using the Statistical Package for Social Sciences (SPSS 20) software. The Chi-square statistical tool was employed for analysis frequency distributions, chi-square goodness-of-fit test, cross-tabulations, and tests of significance. It also allowed investigation of the possible influence of social status on the CR choices of strategies, as well as the 2- cohort-types of respondents and their choice of macro-level strategies and micro-level strategies used to respond to compliments. The standard of $\mathrm{P}$ $<0.05$ was used to show the significance level.

\section{Results and discussion}

\subsection{Analysis of American CRs}

The status variable has been controlled in the very process of designing DCT questionnaire and data collection in order to obtain data that are balanced and all variable values i.e. high, low, equal are proportionally assigned to data points. Therefore, the chi-square goodnessof-fit test was skipped since the numbers have been equally distributed (468 for each). This indicates that further analysis taking the status variable into consideration will provide unbiased results based on a representative sample. Status-based results are also exhibited on two levels- macro and micro-level.

Table 5 highlights adjusted residuals which explain that compliments given by someone of higher status are tended to be more accepted (adjusted residual $=2.6$ ) and ones given by someone of equal status are less accepted (adjust residual $=-3.0$ ). Whereas, non-acceptance is found to be overrepresented between status equals i.e. friends or classmates (adjusted residual $=4.9$ ) and underrepresented with someone from higher status (adjusted residual $=-3.9$ ).

Table 5: Contingency table for macro-level strategies and status relation (American data)

\begin{tabular}{|c|c|c|c|c|c|c|}
\hline \multicolumn{7}{|c|}{ Macrolevel strategies * Status Crosstabulation } \\
\hline & & & \multicolumn{3}{|c|}{ Status } & \multirow[t]{2}{*}{ Total } \\
\hline & & & Lower & Higher & Equal & \\
\hline \multirow{10}{*}{$\begin{array}{c}\text { Macrolevel } \\
\text { strategies }\end{array}$} & \multirow{2}{*}{ Acceptance } & Count & 256 & 275 & 226 & 757 \\
\hline & & Adjusted Residual & .4 & 2.6 & -3.0 & \\
\hline & \multirow{2}{*}{ Amendment } & Count & 74 & 89 & 80 & 243 \\
\hline & & Adjusted Residual & -1.0 & 1.2 & -.1 & \\
\hline & \multirow{2}{*}{ Non-acceptance } & Count & 53 & 36 & 88 & 177 \\
\hline & & Adjusted Residual & -1.0 & -3.9 & 4.9 & \\
\hline & \multirow{2}{*}{ Combination } & Count & 78 & 62 & 64 & 204 \\
\hline & & Adjusted Residual & 1.6 & -1.0 & -.6 & \\
\hline & \multirow{2}{*}{ Opting out } & Count & 7 & 6 & 10 & 23 \\
\hline & & Adjusted Residual & -.3 & -.7 & 1.0 & \\
\hline & Total & Count & 468 & 468 & 468 & 1404 \\
\hline
\end{tabular}

\begin{tabular}{cccc}
\hline \multicolumn{4}{c}{ Chi-Square Tests } \\
& Value & $d f$ & Asymp. Sig. (2-sided) \\
\hline Pearson Chi-Square & $33.441^{a}$ & 8 & .000 \\
\hline Likelihood Ratio & 32.996 & 8 & .000 \\
\hline Linear-by-Linear Association & 1.627 & 1 & .202 \\
\hline Nof Valid Cases & 1404 & & \\
\hline
\end{tabular}

a. 0 cells (0.0\%) have expected count less than 5. The minimum expected count is 7.67. 
The analysis of compliment responses in terms of the status relation between a complimenter and a complimentee reveals some differences among three groups of categorization. Firstly, acceptance is still the most favored strategy out of 5 macrolevel ones; however, when commuting with status equals, respondents chose only $48.30 \%$ whereas respondents of higher status chose $58.60 \%$. Another remarkable difference is situated on the choice of non-acceptance. This macro-level strategy was favored more when it comes to communicating with people of equal status.

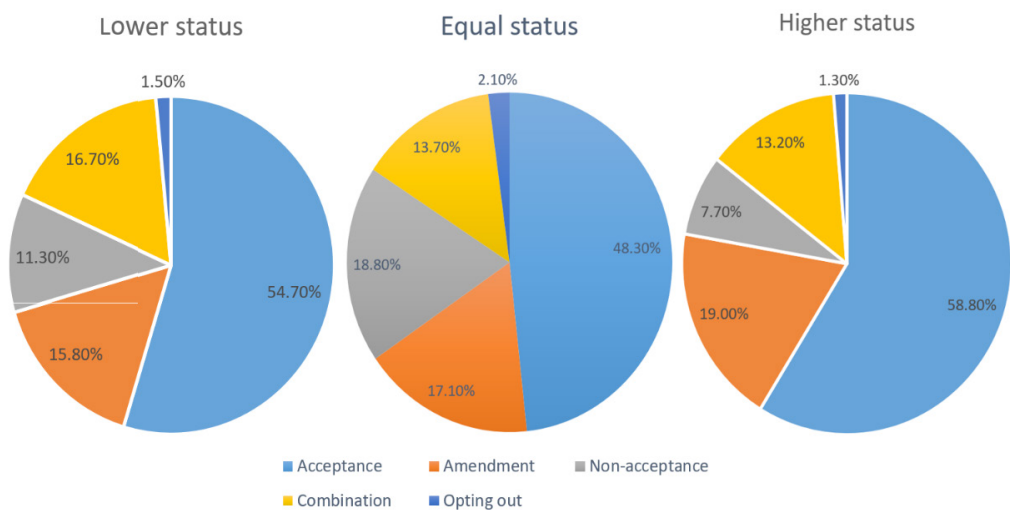

Figure 1: Compliment responses on macro-level across status relations (American data)

When it comes to micro-level strategies, interesting results are found in the choice of some strategies namely expres 2 sing gladness, acceptance association, return, comment, disagreement, combination 1, combination 3 , and opting out with fillers. As can be seen from the highlights in table 6 , there is a small overrepresentation of acceptance association (in people of lower status), return (in people of lower status), comment (in people of higher status), combination 1 (in people of lower status) and opting out with fillers (in people of equal status). This is reflected by

Table 6: Contingency table of micro-level strategies and informants' status (American data)

\begin{tabular}{|c|c|c|c|c|c|c|}
\hline \multicolumn{7}{|c|}{ Micro-level strategies * Status Crosstabulation } \\
\hline & & & Status & & & Total \\
\hline & & & Lower & Higher & Equal & \\
\hline \multirow[t]{5}{*}{$\begin{array}{c}\text { Micro-level } \\
\text { strategies }\end{array}$} & $\begin{array}{c}\text { Appreciation } \\
\text { token }\end{array}$ & Count & 136 & 143 & 139 & 418 \\
\hline & \multirow{2}{*}{ Agreement } & Adjusted Residual & -.4 & .5 & .0 & \\
\hline & & Count & 24 & 18 & 31 & 73 \\
\hline & \multirow{2}{*}{$\begin{array}{c}\text { Expressing } \\
\text { gladness }\end{array}$} & Adjusted Residual & -.1 & -1.6 & 1.7 & \\
\hline & & Count & 36 & 68 & 11 & 115 \\
\hline
\end{tabular}




\begin{tabular}{|c|c|c|c|c|c|c|}
\hline & & Adjusted Residual & -.5 & 6.1 & -5.6 & \\
\hline & Upgrade & Count & 16 & 17 & 10 & 43 \\
\hline & \multirow[b]{2}{*}{ Joke } & Adjusted Residual & .5 & 9 & -1.4 & \\
\hline & & Count & 16 & 14 & 21 & 51 \\
\hline & \multirow{2}{*}{ Laughter } & Adjusted Residual & -.3 & -.9 & 1.2 & \\
\hline & & Count & 1 & 0 & 0 & 1 \\
\hline & \multirow{2}{*}{$\begin{array}{l}\text { Acceptance } \\
\text { association }\end{array}$} & Adjusted Residual & 1.4 & -.7 & -.7 & \\
\hline & & Count & 27 & 14 & 14 & 55 \\
\hline & \multirow{2}{*}{ Return } & Adjusted Residual & 2.5 & -1.3 & -1.3 & \\
\hline & & Count & 20 & 10 & 11 & 41 \\
\hline & & Adjusted Residual & 2.1 & -1.2 & -.9 & \\
\hline & \multirow[b]{2}{*}{ Downgrade } & Count & 5 & 12 & 9 & 26 \\
\hline & & Adjusted Residual & -1.5 & 1.4 & .1 & \\
\hline & \multirow{2}{*}{ Question } & Count & 17 & 14 & 18 & 49 \\
\hline & & Adjusted Residual & .2 & -.7 & .5 & \\
\hline & \multirow{2}{*}{ Comment } & Count & 24 & 49 & 38 & 111 \\
\hline & & Adjusted Residual & -2.7 & 2.5 & .2 & \\
\hline & \multirow{2}{*}{ Transfer } & Count & 8 & 4 & 2 & 14 \\
\hline & & Adjusted Residual & 1.9 & -.4 & -1.5 & \\
\hline & \multirow{2}{*}{$\begin{array}{l}\text { Amendment } \\
\text { association }\end{array}$} & Count & 0 & 0 & 2 & 2 \\
\hline & & Adjusted Residual & -1.0 & -1.0 & 2.0 & \\
\hline & \multirow{2}{*}{ Disagreement } & Count & 43 & 19 & 74 & 136 \\
\hline & & Adjusted Residual & -.4 & -5.0 & 5.5 & \\
\hline & \multirow{2}{*}{ Qualification } & Count & 5 & 7 & 6 & 18 \\
\hline & & Adjusted Residual & -.5 & .5 & .0 & \\
\hline & \multirow[b]{2}{*}{ Diverge } & Count & 5 & 9 & 6 & 20 \\
\hline & & Adjusted Residual & -.8 & 1.1 & -.3 & \\
\hline & \multirow{2}{*}{$\begin{array}{c}\text { Non-acceptance } \\
\text { association }\end{array}$} & Count & 0 & 1 & 2 & 3 \\
\hline & & Adjusted Residual & -1.2 & .0 & 1.2 & \\
\hline & \multirow{2}{*}{ Combination 1} & Count & 63 & 48 & 38 & 149 \\
\hline & & Adjusted Residual & 2.5 & -.3 & -2.1 & \\
\hline & \multirow{2}{*}{ Combination 2} & Count & 9 & 13 & 12 & 34 \\
\hline & & Adjusted Residual & -.9 & .6 & .2 & \\
\hline & \multirow{2}{*}{ Combination 3} & Count & 6 & 1 & 14 & 21 \\
\hline & & Adjusted Residual & -.5 & -2.8 & 3.3 & \\
\hline & \multirow[t]{2}{*}{$\begin{array}{l}\text { Opting out with } \\
\text { fillers }\end{array}$} & Count & 0 & 1 & 5 & 6 \\
\hline & & Adjusted Residual & -1.7 & -.9 & 2.6 & \\
\hline & \multirow{2}{*}{$\begin{array}{c}\text { Opting out with } \\
\text { silence }\end{array}$} & Count & 4 & 2 & 2 & 8 \\
\hline & & Adjusted Residual & 1.0 & -.5 & -.5 & \\
\hline & \multirow{2}{*}{$\begin{array}{l}\text { Opting out with } \\
\text { topic change }\end{array}$} & Count & 1 & 0 & 1 & 2 \\
\hline & & Adjusted Residual & .5 & -1.0 & .5 & \\
\hline & \multirow{2}{*}{$\begin{array}{c}\text { Expressing } \\
\text { embarrassment }\end{array}$} & Count & 2 & 4 & 2 & 8 \\
\hline & & Adjusted Residual & -.5 & 1.0 & -.5 & \\
\hline Total & & Count & 468 & 468 & 468 & 1404 \\
\hline
\end{tabular}

\subsection{Analysis of Vietnamese CRs}

Like American data, Vietnamese data are balanced when the status variable is tested, for the DCT questionnaire and data collection instrument were made with a view to obtaining the data that would show somewhat equally distributed status values (lower, higher, equal) i.e. status variable was a controlled one and hence, the data yielded proportional numbers of data points for each variable values. As such, 
the step to conduct the chi-square goodnessof-fit test was skipped since the test statistics containing a high p-value is rested assured.

The results on the influence of status onto the choice of a compliment response strategy made by Vietnamese informants will be presented from the perspectives of macro- and micro-level strategies.

A look at the chi-square test table in table 7 reveals that status does exert an influence on the choice of macro-level strategies among Vietnamese native speakers. The p-value is 0.00 , which is smaller than the significance value of 0.05 . As the adjusted residuals imply, there some important differences in responding to compliments when status of the interlocutors engaged in a complimenting event is analyzed. It was discovered that people of lower status tended to accept compliments more frequently than it was expected (adjusted residual $=3.8$ ). Meanwhile, one of higher status did not choose to do so (adjusted residual $=-2.2$. In terms of amendment and combination strategies, higher status respondents showed a higher than expected preference towards those (adjusted residual for amendment $=4.2$, adjusted residual for combination $=2.3$ ). In contrast, they showed a reluctance to choose non-acceptance and opting out strategies since the adjusted residuals for both are below -2.0. Regarding the group of status equals, it is observable that they did not very often go for amendment (adjusted residual=-4.4) and combination (adjusted residual=-2.1). In the meantime, there was a great overrepresentation of nonacceptance (adjusted residual=7.4) and opting out strategy (adjusted residual=2.4) among status equals. This may be reasoned by the fact that when communicating with friends or classmates of equal status, respondents are more at ease to turn in their refusal without fearing to lose face of others.

Table 7: Contingency table for macro-level strategies and status relation (Vietnamese data)

\begin{tabular}{|c|c|c|c|c|c|c|}
\hline \multicolumn{7}{|c|}{ Macro-level strategies * Status Crosstabulation } \\
\hline & & & \multicolumn{3}{|c|}{ Status } & \multirow[t]{2}{*}{ Total } \\
\hline & & & High & Low & Equal & \\
\hline \multirow{15}{*}{$\begin{array}{c}\text { Macro-level } \\
\text { strategies }\end{array}$} & \multirow{3}{*}{ Acceptance } & Count & 136 & 186 & 140 & 462 \\
\hline & & Expected Count & 154.0 & 154.0 & 154.0 & 462.0 \\
\hline & & Adjusted Residual & -2.2 & 3.8 & -1.7 & \\
\hline & \multirow{3}{*}{ Amendment } & Count & 158 & 126 & 90 & 374 \\
\hline & & Expected Count & 124.7 & 124.7 & 124.7 & 374.0 \\
\hline & & Adjusted Residual & 4.2 & .2 & -4.4 & \\
\hline & \multirow{3}{*}{ Non-acceptance } & Count & 76 & 64 & 149 & 289 \\
\hline & & Expected Count & 96.3 & 96.3 & 96.3 & 289.0 \\
\hline & & Adjusted Residual & -2.8 & -4.5 & 7.4 & \\
\hline & \multirow{3}{*}{ Combination } & Count & 95 & 78 & 66 & 239 \\
\hline & & Expected Count & 79.7 & 79.7 & 79.7 & 239.0 \\
\hline & & Adjusted Residual & 2.3 & -.3 & -2.1 & \\
\hline & \multirow{3}{*}{ Opting out } & Count & 15 & 26 & 35 & 76 \\
\hline & & Expected Count & 25.3 & 25.3 & 25.3 & 76.0 \\
\hline & & Adjusted Residual & -2.6 & .2 & 2.4 & \\
\hline \multirow{2}{*}{\multicolumn{2}{|c|}{ Total }} & Count & 480 & 480 & 480 & 1440 \\
\hline & & Expected Count & 480.0 & 480.0 & 480.0 & 1440.0 \\
\hline
\end{tabular}




\begin{tabular}{cccc}
\hline \multicolumn{4}{c}{ Chi-Square Tests } \\
\hline Value & $d f$ & Asymp. Sig. (2-sided) \\
\hline Learson Chi-Square & $85.782^{a}$ & 8 & .000 \\
\hline Linear-by-Linear Ratio & 83.790 & 8 & .000 \\
\hline Nof Valid Caseciation & 3.444 & 1 & .063 \\
\hline a. 0 cells $(0.0 \%)$ have expected count less than 5. The minimum expected count is 25.33. \\
\hline
\end{tabular}

Figure 2 brings in a brief summary of Vietnamese choices on macro-level strategies with a view to compare and contrast among three groups of status categorization. As clearly seen from the pie charts, the ranks of 5 macro-level strategies are quite differentiated. In terms of the differences, two points of contrast can be recognized. Firstly, the choice of amendment strategy within the group of higher status, which accounts for the biggest share of all, is surprisingly higher than that of the status equals $(32.92 \%$ and $18.75 \%$ respectively). Another difference lies on the choice of non-acceptance strategy. In comparison with the other groups, status equals were more inclined to decline a compliment. Their percentage of non-acceptance strategy almost doubles those of lower status and higher status groups. (31.04\% vs. $13.33 \%$ and $15.83 \%)$.
Lower status

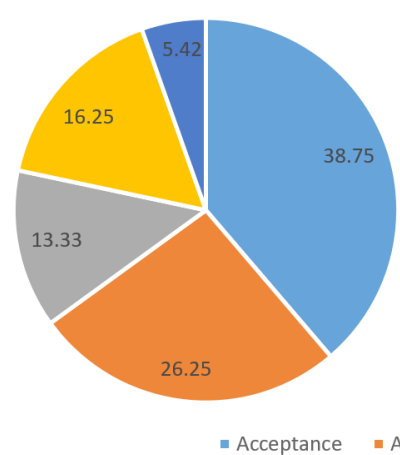

Equal status

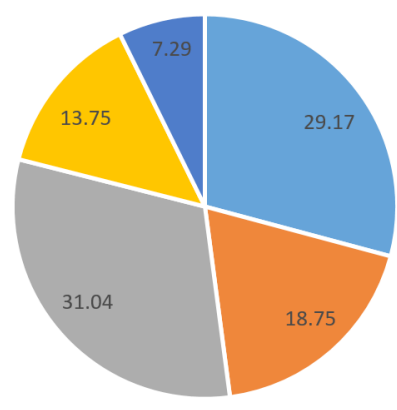

Higher status

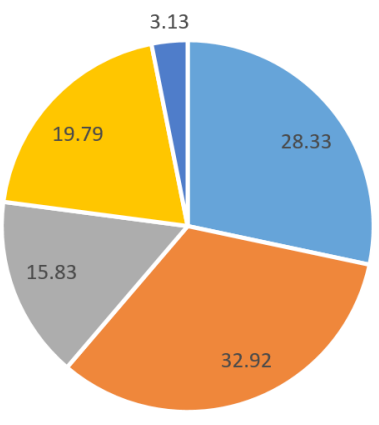

Figure 2: Compliment responses on macro-level across status relation (Vietnamese data)

As regards micro-level strategies and their distribution with respect to status factor, some intriguing and thought-provoking results were obtained (see table 8). First of all, the p-value is smaller than the significance level of 0.05 , which reveals a great statistical influence of status relation on the choices of micro-level strategies. This means that the great differences can be found within 24 sub strategies.

When responding to compliments, ones of lower status were more inclined to shift credit to the complimenters or to the third party (adjusted residual=10.8) whereas they made less use of diverge and question strategy (adjusted residual $=-4.0$ and -4.4 , respectively). This may be seen as an act of politeness from the Vietnamese complimentees since just saying thanks and asking someone of higher status questions may be regarded as being rude.

Regarding the response choices of Vietnamese respondents who were at a higher social distance, it is proven that they rarely chose to reject the compliments (adjusted residual $=-7.5$ ) or shift credit to other (adjust 
residual $=-5.0$ ). On the contrary, they were more at ease to opt for sub strategies such as giving comment (adjusted residual $=3.8$ ), diverging the compliments (adjusted residual= 3.8 ) or making jokes (adjusted residual=2.9).

Lastly, in stark contrast to the choices from ones from lower and higher status, only Vietnamese status equals showed a consuming preference towards the disagreement strategy (adjusted residual $=8.5$ ) and a certain predilection for asking questions (adjusted residual $=4.0$ ). Perhaps, since the interlocutor was friend or classmate, the respondents felt more comfortable to express their inner feelings by rejecting the compliments without the fear of being judged or embarrassing the complimenters.

Table 8: Contingency table of micro-level strategies and informants' status (Vietnamese data)

\begin{tabular}{|c|c|c|c|c|c|c|}
\hline \multicolumn{7}{|c|}{ Micro-level strategies * Status Crosstabulation } \\
\hline & & & \multicolumn{3}{|c|}{ Status } & \multirow[t]{2}{*}{ Total } \\
\hline & & & $\begin{array}{l}\text { Lower } \\
\text { status }\end{array}$ & $\begin{array}{l}\text { Higher } \\
\text { status }\end{array}$ & Equal & \\
\hline \multirow{28}{*}{$\begin{array}{c}\text { Micro-level } \\
\text { strategies }\end{array}$} & \multirow{2}{*}{ Appreciation token } & Count & 73 & 83 & 62 & 218 \\
\hline & & Adjusted Residual & .1 & 1.6 & -1.7 & \\
\hline & \multirow{2}{*}{ Agreement } & Count & 11 & 23 & 22 & 56 \\
\hline & & Adjusted Residual & -2.2 & 1.3 & 1.0 & \\
\hline & \multirow{2}{*}{ Expressing gladness } & Count & 6 & 16 & 3 & 25 \\
\hline & & Adjusted Residual & -1.0 & 3.3 & -2.3 & \\
\hline & \multirow{2}{*}{ Upgrade } & Count & 21 & 16 & 14 & 51 \\
\hline & & Adjusted Residual & 1.2 & -.3 & -.9 & \\
\hline & \multirow{2}{*}{ Joke } & Count & 3 & 22 & 15 & 40 \\
\hline & & Adjusted Residual & -3.5 & 2.9 & .6 & \\
\hline & \multirow{2}{*}{ Laughter } & Count & 4 & 5 & 5 & 14 \\
\hline & & Adjusted Residual & -.4 & .2 & .2 & \\
\hline & \multirow{2}{*}{$\begin{array}{l}\text { Acceptance } \\
\text { association }\end{array}$} & Count & 18 & 21 & 19 & 58 \\
\hline & & Adjusted Residual & -.4 & .5 & -.1 & \\
\hline & \multirow{2}{*}{ Return } & Count & 15 & 14 & 15 & 44 \\
\hline & & Adjusted Residual & .1 & -.2 & .1 & \\
\hline & \multirow{2}{*}{ Downgrade } & Count & 24 & 26 & 26 & 76 \\
\hline & & Adjusted Residual & -.3 & 2 & .2 & \\
\hline & \multirow{2}{*}{ Question } & Count & 2 & 17 & 29 & 48 \\
\hline & & Adjusted Residual & -4.4 & .3 & 4.0 & \\
\hline & \multirow{2}{*}{ Comment } & Count & 49 & 63 & 18 & 130 \\
\hline & & Adjusted Residual & 1.1 & 3.8 & -4.9 & \\
\hline & \multirow{2}{*}{ Transfer } & Count & 61 & 3 & 0 & 64 \\
\hline & & Adjusted Residual & 10.8 & -5.0 & -5.8 & \\
\hline & \multirow{2}{*}{$\begin{array}{l}\text { Amendment } \\
\text { association }\end{array}$} & Count & 7 & 3 & 2 & 12 \\
\hline & & Adjusted Residual & 1.8 & -.6 & -1.2 & \\
\hline & \multirow{2}{*}{ Disagreement } & Count & 61 & 20 & 119 & 200 \\
\hline & & Adjusted Residual & -.9 & -7.5 & 8.5 & \\
\hline
\end{tabular}




\begin{tabular}{|c|c|c|c|c|c|c|}
\hline & \multirow{2}{*}{ Qualification } & Count & 4 & 4 & 1 & 9 \\
\hline & & Adjusted Residual & .7 & .7 & -1.4 & \\
\hline & \multirow{2}{*}{ Diverge } & Count & 9 & 40 & 26 & 75 \\
\hline & & Adjusted Residual & -4.0 & 3.8 & .3 & \\
\hline & \multirow{2}{*}{$\begin{array}{c}\text { Non-acceptance } \\
\text { association }\end{array}$} & Count & 2 & 0 & 3 & 5 \\
\hline & & Adjusted Residual & .3 & -1.6 & 1.3 & \\
\hline & \multirow{2}{*}{ Combination 1} & Count & 63 & 39 & 23 & 125 \\
\hline & & Adjusted Residual & 4.2 & -.5 & -3.7 & \\
\hline & \multirow{2}{*}{ Combination 2} & Count & 7 & 27 & 19 & 53 \\
\hline & & Adjusted Residual & -3.2 & 2.8 & .4 & \\
\hline & \multirow{2}{*}{ Combination 3} & Count & 25 & 12 & 24 & 61 \\
\hline & & Adjusted Residual & 1.3 & -2.3 & 1.0 & \\
\hline & \multirow{2}{*}{$\begin{array}{l}\text { Opting out with } \\
\text { fillers }\end{array}$} & Count & 0 & 0 & 1 & 1 \\
\hline & & Adjusted Residual & -.7 & -.7 & 1.4 & \\
\hline & \multirow{2}{*}{$\begin{array}{l}\text { Opting out with } \\
\text { silence }\end{array}$} & Count & 4 & 10 & 16 & 30 \\
\hline & & Adjusted Residual & -2.3 & .0 & 2.3 & \\
\hline & \multirow{2}{*}{$\begin{array}{l}\text { Opting out with } \\
\text { topic change }\end{array}$} & Count & 4 & 7 & 10 & 21 \\
\hline & & Adjusted Residual & -1.4 & .0 & 1.4 & \\
\hline & \multirow{2}{*}{$\begin{array}{c}\text { Expressing } \\
\text { embarrassment }\end{array}$} & Count & 7 & 9 & 8 & 24 \\
\hline & & Adjusted Residual & -.4 & .4 & .0 & \\
\hline Total & & Count & 480 & 480 & 480 & 1440 \\
\hline
\end{tabular}

\subsection{Discussion}

The significant values (smaller than 0.01) from the chi-square test in both American and Vietnamese native groups of informants indicate that social status exerts a certain impact on the choices of CR strategies. However, the influence of social status on each group's CR choices is quite varied.

In terms of the American group, compliment receivers of higher status tended to accept more than deny a positive comment. In contrast, it is more frequent among equal interactions to turn down a compliment than to accept. This seems to correlate with the Politeness theory proposed by Brown and Levinson (1987). To be specific, people choose to accept the compliment given by ones of lower status in order to save face for the compliment giver and in other words, to preserve the harmony and maintain the positive face during communicative exchanges. In terms of social equals, since there exists a certain degree of intimacy with each other, they found it easier to express themselves and maintain their negative face without the fear of being misunderstood as being impolite or rude.

Regarding the impact of social status on the Vietnamese group, it is observable that the Vietnamese reacted quite differently when the communicating partners were ones of different status. Notably, ones of higher status made use of amendment and combination more often than acceptance and non-acceptance. On the contrary, ones of lower status more frequently chose to accept the compliment. Finally, towards social equals, Vietnamese informants were found to unexpectedly turn down a compliment rather than amend it. To reason for that, it is important to look back at the influence of Chinese culture on ours. For such a long time, Vietnamese culture is deeply rooted by the Confucian ideology from China, 
especially the Five Constant Virtues including Kindness, Decorum, Uprightness, Wisdom and Faithfulness, among which Uprightness implies the respectfulness towards ones of higher status and harmony with ones of equal and lower status during social interactions. Thus, it may seem awkward or somehow rude if they just accept or turn down the positive comments from ones of higher status. In this regard, this reasons for the fact that acceptance is by far not the most preferred strategy of Vietnamese respondents. However, in case of equal status interaction, it seems that the Vietnamese informants are less constrained to react to compliments. One evidence is that the non-acceptance occurred at the highest rate out of the five macro-level strategies. Using rejecting strategies is considered an instance of adhering to the Modesty Maxim as based on Leech (1983), which means that the complimentee tries to attend to his or her own positive face so that his or her behavior can be regarded as polite and not to save the complimenter's positive face.

Concerning the relative social factors of distance and power, the politeness systems suggested by Scollon and Scollon (2001) could apply to all the recorded response types.

The assumptions of unequal power status and distant relations of the hierarchical politeness system set the ground for the respondents to suggest acceptance, nonacceptance, and amendment strategies. In such almost alien contexts the respondents behaved differently in their application of compliment response categories. First, the lower status addresses tried to establish "common grounds" (Chen, 1993, p. 58) with their speakers giving their gladness accounts or express their gratitude via thanking them. Commenting was also used in addressing the superordinates to slightly decrease the worth of the object by an emphasis on the role of factors like a long period of exercising, the price, etc. Then, to agree with the complimenter and avoid self-praise at the same time the subordinate respondents took refuge in downgrade and qualification response categories to indicate two things: either to play down the value of the complimented objects by referring to their defects or to suggest the praised trait as merely a requirement of their tasks not a sort of natural talent.

The deferential politeness system encompassed equal social distance in the interactional contexts. In such situations the participants are supposed to suggest their responses out of respect for their addresser. With this background, the complimentees frequently tended to return the complimentary force to the speaker in an attempt to maximize benefit to him/her, too, in line with the earlier noted Tact Maxim. Furthermore, such respect in a strong sense could even lead the recipients to disagree with the speaker in spite of the truth of the compliment.

The third solidarity politeness system entailed equal, close relations between the interlocutors out of which neutral elaboration major response category was raised. Questioning the truth of the statements as well as assigning the reasons of the success to other third person forces resulted from this category in the respondents' attempts to avoid self-praise.

\section{Conclusion}

The present study tried to contribute to the existing literature on speech acts, in general and compliment responding, in particular. A focus on the sociolinguistic variable of status in performing such illocutionary acts proved helpful in examining the unnoticed or less attended-to-corners of the earlier 
studies. As to the social distance concerns, acceptance response category was grounded in hierarchical politeness system while return rooted in the deferential politeness system and solidarity politeness system raised the nonacceptance response category.

Although through this study, the attempt was made to select the participants from different parts of both countries, the results cannot be generalized to all the American and Vietnamese native speakers with certainty. Meanwhile, the unveiled complexities might help the speakers from both cultures in selection of their compliment responses.

\section{References}

Baba, J. (1999). Interlanguage pragmatics: Compliment responses by learners of Japanese and English as a second language, (Vol. 4). Lincom Europa.

Blum-Kulka, S., House, J., \& Kasper, G. (1989). Crosscultural pragmatics: Requests and apologies (Vol. 31). Ablex Pub.

Brown, P., Levinson, S. C., \& Levinson, S. C. (1987). Politeness: Some universals in language usage (Vol. 4). Cambridge university press.

Chen, R. (1993). Responding to compliments A contrastive study of politeness strategies between American English and Chinese speakers. Journal of Pragmatics, 20(1), 49-75.

Chen, R. (2001). Self-politeness: A proposal. Journal of pragmatics, 33(1), 87-106.

Chen, R. (2010). A cross-cultural survey of research on complimenting and compliment responding. Handbook of Pragmatics, 7.

Daikuhara, M. (1986). A study of compliments from a cross-cultural perspective: Japanese vs. American English. Working Papers in Educational Linguistics (WPEL), 2(2), 6.

Farghal, M., \& Al-Khatib, M. A. (2001). Jordanian college students' responses to compliments: A pilot study. Journal of Pragmatics, 33(9), 1485-1502.

Farghal, M., \& Haggan, M. (2006). Compliment behaviour in bilingual Kuwaiti college students. International Journal of Bilingual Education and Bilingualism, 9(1), 94-118.

Fukushima, N. J. (1990). A study of Japanese communication: compliment-rejection production and second language instruction (Doctoral dissertation, University of Southern California).

Gajaseni, C. (1995). A contrastive study of compliment responses in American English and Thai including the effect of gender and social status (Unpublished doctoral dissertation). University of Illinois.
Golato, A. (2002). German compliment responses. Journal of Pragmatics, 34(5), 547-571.

Han, C. H. (1992). A Comparative Study of Compliment Responses: Korean Females in Korean Interactions and in English Interactions. Working Papers in Educational Linguistics, 8(2), 17-31.

Herbert, R. K. (1986). Say" thank you"-or something. American speech, 61(1), 76-88.

Herbert, R. K. (1990). Sex-based differences in compliment behavior 1. Language in Society, 19(2), 201-224.

Herbert, R. K. (1991). The sociology of compliment work: An ethnocontrastive study of Polish and English compliments. Multilingua-Journal of CrossCultural and Interlanguage Communication, 10(4), 381-402.

Herbert, R. K., \& Straight, H. S. (1989). Complimentrejection versus compliment-avoidance: Listener-based versus speaker-based pragmatic strategies. Language \& Communication.

Holmes, J. (1986). Compliments and compliment responses in New Zealand English. Anthropological linguistics, 485-508.

Holmes, J. (1988). Paying compliments: A sexpreferential politeness strategy. Journal of pragmatics, 12(4), 445-465.

Jaworski, A. (1995). "This is not an empty compliment!" Polish compliments and the expression of solidarity 1. International Journal of Applied Linguistics, 5(1), 63-94.

Leech, G. (1983). Principles of pragmatics. London and New York: Longman.

Lorenzo-Dus, N. (2001). Compliment responses among British and Spanish university students: A contrastive study. Journal of Pragmatics, 33(1), 107-127.

Manes, J. (1983). Compliments: A mirror of cultural values. Sociolinguistics and language acquisition, 5(3), 96-106.

Migdadi, F. H. (2003). Complimenting in Jordanian Arabic: A socio-pragmatic analysis.

Mustapha, A. S. (2004). Gender variation in Nigerian English compliments (Doctoral dissertation, University of Essex).

Nelson, G., Al-Batal, M., \& Echols, E. (1996). Arabic and English compliment responses: Potential for pragmatic failure. Applied Linguistics, 17(4), 411432.

Pomerantz, A. (1978). Compliment responses: Notes on the co-operation of multiple constraints. In Studies in the organization of conversational interaction ( $\mathrm{pp}$. 79-112). Academic Press.

Pomerantz, A. (1978). Compliment responses: Notes on the co-operation of multiple constraints. In Studies in the organization of conversational interaction (pp. 79-112). Academic Press.

Pomerantz, A. (1984). Agreeing and disagreeing with assessments: Some features of preferred/ dispreferred turn shaped.

Ruhi, S. (2006). Politeness in compliment responses. Pragmatics. Quarterly Publication of the 
International Pragmatics Association (IPrA), 16(1), 43-101.

Ruhi, Ş., \& Doğan, G. (2001). Relevance theory and compliments as phatic communication. Linguistic Politeness Across Boundaries. The Case of Greek and Turkish, 341-390.

Saito, H., \& Beecken, M. (1997). An approach to instruction of pragmatic aspects: Implications of pragmatic transfer by American learners of Japanese. The Modern Language Journal, 81(3), 363-377.

Scollon, R., \& Scollon, S. W. (2001). Discourse and Intercultural Communication. The Handbook of Discourse Analysis, 538.

Sharifian, F. (2005). The Persian cultural schema of shekasteh-nafsi: A study of compliment responses in Persian and Anglo-Australian speakers. Pragmatics \& Cognition, 13(2), 337-361.

Spencer-Oatey, H., \& Ng, P. (2001). Reconsidering Chinese modesty: Hong Kong and mainland Chinese evaluative judgements of compliment responses. Journal of Asian Pacific Communication, 11(2), 181-201.

Tang, C. H., \& Zhang, G. Q. (2009). A contrastive study of compliment responses among Australian English and Mandarin Chinese speakers. Journal of Pragmatics, 41(2), 325-345.
Temple,B.(1997). Watchyourtongue:Issues in translation and cross-cultural research. Sociology, 31(3), 607618.

Wilson, D., \& Sperber, D. (1993). Linguistic form and relevance. Lingua, 90(1), 1-25.

Wolfson, N. (1983). An empirically based analysis of complimenting in American English. Sociolinguistics and Language Acquisition, 443, 82-95.

$\mathrm{Yu}$, M. (2000). Cross-cultural and interlanguage pragmatics: Developing communicative competence in a second language (Taiwan).

Yu, M. C. (2003). On the universality of face: Evidence from Chinese compliment response behavior. Journal of pragmatics, 35(10-11), 16791710.

Yu, M. C. (2004). Interlinguistic variation and similarity in second language speech act behavior. The Modern Language Journal, 88(1), 102-119.

Yu, M. C. (2005). Sociolinguistic competence in the complimenting act of native Chinese and American English speakers: A mirror of cultural value. Language and speech, 48(1), 91-119.

Yuan, Y. (2002). Compliments and compliment responses in Kunming Chinese. Pragmatics, 12(2), 183-226.

\title{
NGHIÊN CỬU ẢNH HƯởNG CỦA KHOẢNG CÁCH XÃ HộI TỚI CÁC CHIẾN LƯợC ĐÁP LẠI LỜI KHEN TRONG TIẾNG ANH MỸ் VÀ TIẾNG VIỆT
}

\author{
Nguyễn Thị Thùy Linh \\ Truờng Đại họ Ngoại ngũ - ĐHQGHN, \\ Phạm Văn Đồng, Cầu Giáy, Hà Nội, Việt Nam
}

Tóm tắt: Nghiên cứu này được thực hiện nhằm mục đích điều tra ảnh hưởng của khoảng cách xã hội đối với việc lựa chọn chiến lược đáp lại lời khen trong tiếng Anh Mỹ và tiếng Việt. Để làm được điều này, hai bộ dữ liệu đã được thu thập bằng công cụ Bảng câu hỏi điền khuyết (DCT) với 12 câu hỏi tình huống trong đó người khen là những người có địa vị cao hơn, bằng hoặc thấp hơn nghiệm thể. Phân tích thống kê cung cấp những kết quả thống kê mô tả liên quan tới các chiến lược đáp lại lời khen ở 2 cấp đô, vĩ mô và vi mô. Nói cách khác, những kết quả này thể hiện các chiến lược tiếp nhận lời khen bao gồm: chấp nhận, sửa đổi, không chấp nhận, kết hợp và lảng tránh. Ngoài ra, số liệu thống kê suy luận còn chỉ ra rằng liệu có hay không một tiêu chuẩn chung trong việc lựa chọn các chiến lược đáp lại lời khen giống nhau giữa người Mỹ và người Việt. Cuối cùng, những kết quả thu được chỉ ra rằng có một ảnh hưởng nhất định giữa sự khác biệt trong khoảng cách xã hội và các cách thức đáp lại lời khen.

Tù khóa: khen, đáp lại lời khen, khoảng cách xã hội 


\section{APPENDIX \\ DISCOURSE COMPLETION TASK (DCT) QUESTIONNAIRE}

Gender:

Thank you first for showing interest in participating in this study. You are kindly asked to fill out this questionnaire to contribute to a research project on "Compliment responses". What you are invited to do is to imagine yourself in a situation where you are being complimented by acquaintances and write down what you would say back to the compliments. There are a total number of 12 situations in this questionnaire.

In reply to the questions:

Please do this survey by yourself.

Please make the responses the way you think it is naturally occurring in real life situations.

If you would be prepared to take part in a follow-up group interview for the discussion of survey results, please let me contact via email or any kinds that you feel comfortable.

Contact:
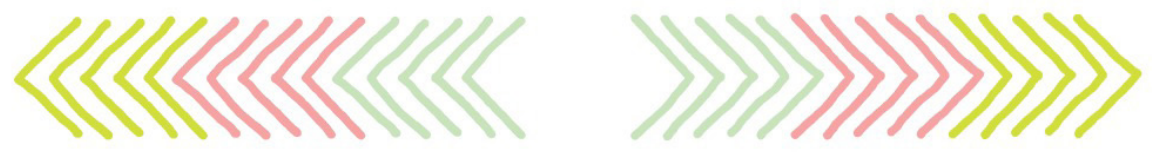

Thank you for your participation!

\section{Situation 1.}

You have just successfully defended your bachelor's thesis with high distinction. Your supervisor is really happy about that. She says, "Well-done! It was a pleasure to work with you!". You say in response:

\section{Situation 2.}

You pay a visit to your parents-in-law at the weekend. Before the meal, you notice your mother in-law is busy preparing a big dinner. You approach and give her a helping hand without being asked. She really appreciates your enthusiasm saying, "You're very thoughtful! It would have been a mess without your help".

You say in response:

\section{Situation 3.}

After the new year holiday, you come back to work. To have a good start, you decided to pick the best outfit of yours in the wardrobe in the morning. On seeing you, your female boss says, "You look great! I hardly recognize you today!".

You say in response:

\section{Situation 4.}

You have just had your first baby. Your boss and colleagues come to visit you and the baby at home. She says, "Let me look at the little angel. What a cute chubby little boy!". 
You say in response:

\section{Situation 5.}

You are a high school English language teacher. You have just had a lesson on the topic "How to write a persuasive opinion essay?". The students show a lot of interest in the lesson since it is rich in practical advice with valuable tips for essay writing. After class, a female student of yours comes to you and says, "Thank you for your inspiring lesson! I learned a lot!".

You say in response:

\section{Situation 6.}

In the year-end party of your division, as the head manager, you have some nice words of appreciation for a hard-working year of your staff. Your speech is full of humors and your staff really enjoy it. A female subordinate comes to you afterwards and says, "I didn't know that you're such a man of humor!"”.

You say in response:

\section{Situation 7.}

You have just lost some weight and look fitter after several weeks of intensive workout. Your little nephew notices this change. He says, "Wow! You look like a movie star!".

You say in response:

\section{Situation 8.}

You are the director of a trading company. You have just bought a new sedan car and today you drive it to work. Your subordinate, seeing it comes to congratulate you on that. He says, "What a nice car!"

You say in response:

\section{Situation 9.}

You are a university student. With high scores, you are awarded a scholarship for the next semester. A male classmate of yours says, "You deserve it! Way to go!".

You say in response:

\section{Situation 10.}

Your class is going on a field trip to a forest. Unfortunately, one of your female classmates trips over a stone and gets hurt. As the only boy nearby, you offer her a piggyback ride. She says, "You're a great help! Thanks a lot!".

You say in response:

\section{Situation 11.}

You have just had your haircut today. Seeing you at the café, a male friend of yours says, "Hey, you look 5 years younger!".

You say in response:

\section{Situation 12.}

After months of saving, you have managed to buy a new MacBook laptop. Your best friend is very happy for you. He says, "You look smarter with this new MacBook!".

You say in response: 